\title{
Replication of Grapevine leafroll-associated virus-7 (GLRaV-7) by Cuscuta Species and Its Transmission to Herbaceous Plants
}

Cord Mikona and Wilhelm Jelkmann, Julius Kuehn Institute (JKI), Federal Research Centre for Cultivated Plants, Institute for Plant Protection in Fruit Crops and Viticulture, Schwabenheimer Str. 101, 69221 Dossenheim, Germany

\begin{abstract}
Mikona, C., and Jelkmann, W. 2010. Replication of Grapevine leafroll-associated virus-7 (GLRaV-7) by Cuscuta species and its transmission to herbaceous plants. Plant Dis. 94:471-476.

Grapevine leafroll-associated virus-7 (GLRaV-7) was transmitted from an Albanian grapevine accession to Tetragonia expansa by the parasitic dodder Cuscuta reflexa and to Nicotiana occidentalis by Cuscuta europea. Cuscuta campestris was infected by GLRaV-7 but could not transfer the virus to an experimental host. Transmission of the virus was verified by reverse transcription-polymerase chain reaction (RT-PCR) from total nucleic acid (TNA) and double-stranded RNA (dsRNA) extracts from all five plant species. DsRNA extractions separated on agarose gels showed strong visible bands corresponding to high-molecular-weight virus genome and to subgenomic RNA. GLRaV-7 was maintained in C. reflexa, C. campestris, T. expansa, and N. occidentalis for more than 4 years. Infected T. expansa and the Cuscuta species remained symptomless while $N$. occidentalis showed severe symptoms leading to stunting and decline of the plants. Quantitative PCR showed great differences in the titer of GLRaV-7 between the tissues of its natural and experimental host plants. This is the first report on a virus of the Closteroviridae that was successfully transmitted to an herbaceous plant by dodder. Virus replication could be demonstrated in Cuscuta. Both the new experimental hosts of GLRaV-7 and Cuscuta allowed extraction of dsRNA for further characterization of the viral genome, which previously required grapevine scraping of phloem. This is time-consuming and does not always lead to satisfactory results. These alternative hosts of GLRaV-7 facilitate nucleic acid extractions and could be used as model plants for etiological studies.
\end{abstract}

Virology has greatly benefited from the use of Cuscuta species as vectors to transfer viruses from one host to another. The genus Cuscuta consists of approximately 160 species (42) which were formerly treated as one genus in the family $\mathrm{Cuscu}$ taceae. Recent genetic research, however, provided evidence to group the genus in the family Convolvulaceae $(24,33,34)$. As a holoparasite, dodder species depend entirely on their host plant, from which they receive nutrients. During the establishment of the interaction, a haustorium is formed that penetrates the host tissue and generates an open continuity between the host phloem and the parasite phloem (4). Following this, a transfer of macromolecular substances in both directions (14) takes place, providing a basis for the exchange of proteins, genes, and mRNA $(22,27)$. As one dodder plant can attach simultaneously to unrelated host species, a connection between the phloem of graft-incompatible species is possible.

Corresponding author: W. Jelkmann

E-mail: Wilhelm.Jelkmann@jki.bund.de

Accepted for publication 3 December 2009.

doi:10.1094/PDIS-94-4-0471

This article is in the public domain and not copyrightable. It may be freely reprinted with customary crediting of the source. The American Phytopathological Society, 2010.
Since 1940, when dodder transmission of viruses from one host to another was discovered (3), many transmission experiments have been carried out (for review see Hosford, 1967 [15]). Besides exploring the potential host range of a virus, the transmission to mostly herbaceous host plants was performed to improve speed and reliability of virus detection. Now, molecular and serological tools are available that are faster and more accurate than biological tests. However, dodder transmission is still a valuable tool for specific purposes like the transmission of a virus from a low titer host to a high titer host, particularly if the natural vector is unknown and mechanical inoculation is not possible. The transmission to an experimental host like tobacco, Chenopodium quinoa, or even dodder guarantees the availability of plant material throughout the year with adequate plant pathogen titers (19). It has been shown that purifying viral RNA from tree or other plant tissues that contain high levels of phenolic or polysaccharide compounds is particularly difficult, with extraction being often time-consuming and the nucleic acid yield not always satisfactory $(7,28)$. Therefore, an experimental herbaceous virus source for those viruses is a desirable objective. This is the case for Grapevine leafroll-associated virus-7 (GLRaV-7), a filamentous, phloem-limited virus that was first found in white-berried grapevine accessions in Albania (5).
After infecting host plants, the viral single-stranded RNA replicates in plant phloem tissue. During replication, doublestranded RNA (dsRNA) is generated as an intermediate product $(8,39)$. The advantages of dsRNA for the characterization of GLRaV-7 are its resistance to enzymatic degradation and its ability to simultaneously modify both $5^{\prime}$ and $3^{\prime}$ terminal ends (tailing or primer specific reverse transcription) for sequence determination $(9,13,39)$. GLRaV-7 is not yet assigned to a genus in the family Closteroviridae (20). The family Closteroviridae comprises three genera, but only the genus Closterovirus contains species like Grapevine leafroll-associated virus-2 that are transmissible by mechanical inoculation. Viruses of the genera Ampelovirus and Crinivirus are not mechanically transmissible (20). The mode of transmission for the unassigned GLRaV-7 and the nature of a possible vector are unknown. There have been reports on the successful mechanical transmission of grapevine leafroll-associated viruses to healthy grapevine or herbaceous plants (Nicotiana spp.) $(35,41)$. However, the experiments did not differentiate between GLRaV species. As all attempts to transmit GLRaV-7 mechanically to an herbaceous host in the present study failed, virus translocation by dodder was explored. Three Cuscuta species were selected based on previous experience with them in phytoplasma transmission experiments (19).

In this study, we demonstrate that the transmission of GLRaV-7 by dodder to several herbaceous plants facilitates the extraction of its nucleic acids to obtain sufficient amounts of RNA as starting material for characterization of the GLRaV-7 genome.

\section{MATERIALS AND METHODS}

Plant material and propagation. Three different dodder species, Cuscuta reflexa Roxb. (giant dodder), Cuscuta campestris Yuncker (western field dodder), and Cuscuta europea L. (greater dodder), were used as vectors. GLRaV-7-free C. reflexa was available from vegetatively propagated material maintained on nettle (Urtica dioica L.) in the greenhouse. Seeds of $C$. campestris and $C$. europea were germinated on moist filter paper or soil and transferred to healthy $N$. occidentalis for initial development. $N$. occidentalis 37B and Tetragonia expansa (New Zealand 
spinach) plants were grown from seeds. Vitis vinifera L. used for transmission experiments were cloned from stem cuttings of the Albanian grapevine accession AA42 (29).

Transmission experiments. Transmission was initiated in spring and summer in an insect-proof greenhouse at temperatures between 20 and $30^{\circ} \mathrm{C}$ (relative humidity approximately $60 \%$ ). After 3 weeks of growth on healthy tobacco, the dodder shoots were connected to grapevine plants infected with GLRaV-7 and to healthy $N$. occidentalis. After 3 months, the parasite was removed completely from the virus donor and acceptor and put on young nettle and tobacco plants for maintenance. During this time, the first extractions and virus detections were carried out.

Transmission experiments of GLRaV-7 by infected $C$. reflexa to herbaceous plants like Solanum lycopersicum, Capsicum annuum, Cucumis sativus, Cucurbita pepo, T. expansa, and Physalis peruviana were performed.

Virus detection. GLRaV-7 infection of plants and seedlings was verified by reverse transcription-polymerase chain reaction (RT-PCR) of extracted material. Virus testing of plants was carried out 2 months after the beginning of the transmission experiments and subsequently every 2 to 3 months.

Isolation of total nucleic acids and dsRNA. Total nucleic acids were extracted from stipes and midribs according to a modified silica capture procedure described by Rott and Jelkmann (28). Briefly, for dsRNA extraction, $10 \mathrm{~g}$ of fresh leaf tissue were extracted essentially as described by Keim-Konrad and Jelkmann (17). DsRNA was separated by gel electrophoresis in $1 \%$ agarose gel containing ethidium bromide and visualized under UV light. High-molecular-weight bands corresponding to dsRNA of Closteroviridae were excised and gel-purified with the QIAEX II gel extraction kit (Qiagen).

cDNA synthesis and PCR. RNA was reverse transcribed with random hexamer primers (Fermentas). Two microliters of nucleic acid extract (equivalent to approximately $4.5 \mathrm{mg}$ of extracted plant material) was added to $12.5 \mu \mathrm{l}$ of sterile water including $200 \mathrm{ng}$ of random hexanucleotides (Invitrogen). The RNA was denatured at $70^{\circ} \mathrm{C}$ for $10 \mathrm{~min}$ and chilled on ice; $5.5 \mu \mathrm{l}$ of an RT-mix containing $50 \mathrm{mM}$ Tris- $\mathrm{HCl}, 50 \mathrm{mM} \mathrm{KCl}, 4 \mathrm{mM} \mathrm{MgCl}_{2}, 10$ mM DTT, $500 \mu \mathrm{M}$ each dNTP, and 100 units of Reverse Transcriptase (Fermentas) was added and incubated for $10 \mathrm{~min}$ at $37^{\circ} \mathrm{C}$ followed by $60 \mathrm{~min}$ at $42^{\circ} \mathrm{C}$. A final heating at $70^{\circ} \mathrm{C}$ for $10 \mathrm{~min}$ was used for enzyme inactivation.

Reverse transcription of dsRNA was initiated by boiling $5 \mu \mathrm{l}$ of gel-purified dsRNA on average (equivalent to $1 \mathrm{~g}$ of extracted plant material) with $500 \mathrm{ng}$ of random hexanucleotides (Invitrogen) in a volume of $15 \mu \mathrm{l}$ for $10 \mathrm{~min}$ and subsequent freezing in liquid nitrogen; $25 \mu \mathrm{l}$ of RTmix containing $50 \mathrm{mM}$ Tris- $\mathrm{HCl}, 50 \mathrm{mM}$ $\mathrm{KCl}, 4 \mathrm{mM} \mathrm{MgCl} 2,10 \mathrm{mM}$ DTT, $500 \mu \mathrm{M}$ each dNTP, 40 units of Ribonuclease Inhibitor (Fermentas), and 200 units of Reverse Transcriptase (Fermentas) was added. Incubation times and enzyme inactivation were as described above.

PCR amplification was performed in a $25-\mu \mathrm{l}$ volume containing 0.5 to $2 \mu \mathrm{l}$ of cDNA, $20 \mathrm{mM}$ Tris-HCl (pH 8.4), $50 \mathrm{mM}$ $\mathrm{KCl}, 2 \mathrm{mM} \mathrm{MgCl} 2,0.15 \mathrm{mM}$ each dNTP, $0.5 \mu \mathrm{M}$ each primer, and 1 unit of Taq DNA Polymerase (Invitrogen). The primers GLRaV-7F (5'-GGGAGGATCGTC GTTGCTAAGT-3', positionGLRaV-7 95589579) and GLRaV-7R (5'-TTCCCC AGGTCGAGATACAGAGTC-3', positionGLRaV-7 9942-9919) were used for amplification of a 385-bp PCR product. The reaction was cycled in a Stratagene Robocycler with the following parameters: $95^{\circ} \mathrm{C}$ for $4 \mathrm{~min}$ followed by 30 cycles at $95^{\circ} \mathrm{C}$, annealing at $52^{\circ} \mathrm{C}$, and extension at $72^{\circ} \mathrm{C}$, each step for $45 \mathrm{~s}$. The final incubation was carried out at $72^{\circ} \mathrm{C}$ for $10 \mathrm{~min}$ to assure complete extension of the strands. PCR products were separated by gel electrophoresis in $1 \%$ agarose gel containing ethidium bromide and visualized under UV light.

Real-time PCR with internal standard. Competitive real-time PCR was carried out to quantify and compare the GLRaV-7 titer of different host plants and different plant tissues. Therefore, extractions from the following four different tissues of grapevine accession AA42, $N$. occidentalis, and T. expansa were used: midrib, leaf tissue (without midrib), phloem, and roots. Because no tissue differentiation was possible in GLRaV-7infected Cuscuta species, whole shoots were extracted for real-time PCR.

All real-time PCR were performed in a BioRad iCycler using 96-well reaction plates sealed with optical adhesive covers (BioRad). Real-time PCR was conducted using SYBR Green I (Roche) in a $50-\mu l$ reaction with the following content: $2 \mu \mathrm{l}$ of cDNA template, 1× TEMPase Hot Start Buffer I (Ampliqon), $0.2 \mathrm{mM}$ each dNTP, $0.2 \mu \mathrm{M}$ each primer, and 1.25 units TEMPase Hot Start DNA Polymerase (Ampliqon). The primers F_GLRaV-7_2006-B (5'-CATGCTAACGCTGGAAACAAAAG AT-3', position 14155-14179) and R_GLRaV-7_2006-Z (5'-TCTTCAGAG GCTCTACCGGTCTT-3', position 1433214310) were used for amplification of a 178-bp PCR product. For each sample, two real-time PCR were carried out to check the accuracy of quantification. The calculated mean values of the two measurements were used for tissue and host comparison.

The PCR cycling program consisted of an initial activating and denaturing step at $95^{\circ} \mathrm{C}$ for $30 \mathrm{~min}$, followed by 40 cycles at $94^{\circ} \mathrm{C}$ for $20 \mathrm{~s}, 52^{\circ} \mathrm{C}$ for $30 \mathrm{~s}$, and $72^{\circ} \mathrm{C}$ for 30 s. Quantification of GLRaV-7 RNA was performed by cycling a $10^{1}$ to $10^{6}$ dilution of a cloned viral DNA fragment in parallel. The DNA standard consisted of a titrated single-stranded phage whose copies were determined by plating and colony counting.

Northern blot analysis. To confirm GLRaV-7 infections, Northern blot analysis was carried out as described (30). DIGlabeled probes were generated from purified GLRaV-7 dsRNA using the PCR DIG Probe Synthesis Kit (Roche) per manufacturer's instructions. The same primer pair as for real-time PCR was used. Detection was performed using the DIG High Prime DNA Detection Starter Kit II (Roche) per manufacturer's instructions.

\section{RESULTS}

GLRaV-7 transmission and replication. The parasites accepted grapevine and the herbaceous host plants equally well. The establishment of stable connections between Cuscuta species and its primary hosts were formed after 1 to 2 weeks (Fig. 1). The dodder was attached for 2 to 3 months depending on the growth rate of dodder and the decline of the infested plants.

The results of the virus transmission experiments are presented in Table 1 . GLRaV-7 is transmissible by means of dodder. All three dodder species were able to take up GLRaV-7, but the transmission of the virus to herbaceous hosts was only successful in the following plant-parasite combinations: $C$. reflexa transmitted GLRaV-7 to T. expansa, and C. europea to $N$. occidentalis, respectively. C. campestris was able to take up the virus but without transmitting it to new hosts. GLRaV-7 was able to replicate in T. expansa, $N$. occidentalis, and the dodder species. Replication of GLRaV-7 was demonstrated by dsRNA extraction showing identical profiles as compared to grapevine and $N$. occidentalis or T. expansa (Fig. 2). The infection in $C$. europea could not be maintained due to the drying-out of the parasite after flowering and seeding.

Transmission experiments to Catharanthus roseus, Solanum lycopersicum, Capsicum annuum, Cucumis sativus, Cucurbita pepo, and Physalis peruviana with GLRav-7-infected $C$. reflexa were performed, but the plants remained free of symptoms and GLRaV-7-free (RT-PCR detection). Test plants inoculated by dodder transmission were observed for up to 3 months.

Symptoms and detection of viral RNA. None of the new host plants showed any visible symptoms after infection with GLRaV-7 except for $N$. occidentalis. After 4 to 6 weeks, the tobacco developed systemic symptoms such as vein clearing, microphyllous and necrotizing leaves, and stunting. The severity of systemic symptoms increased during the following weeks 
and led to a decline of the affected plants (Fig. 3). DsRNA extractions from the diseased N. occidentalis, as well as from Cuscuta spp. and T. expansa, showed typical virus bands in agarose gel electrophoresis corresponding to high-molecular-weight viral RNA and to subgenomic RNA (Fig. 2 ). The dsRNA yield was estimated between 30 and less than $250 \mathrm{ng}$ per $10 \mathrm{~g}$ of leaf tissue. The presence of GLRaV-7 was confirmed by virus-specific RT-PCR of purified dsRNA extract as well as of total nucleic acid extract (Fig. 4).

Maintenance of GLRaV-7 infection. After successful virus transmission to dodder plants, GLRaV-7-infected C. reflexa was maintained on Urtica dioica and $C$. campestris on $N$. occidentalis over a period of 4 years. Over this period, GLRaV-7 was regularly detected by dsRNA extraction in newly grown $C$. reflexa tissue in equal amounts of nucleic acids as judged by gel electrophoresis. Northern blots were performed as a confirmatory approach (data not shown) and were able to confirm differentially that dodder growing and living off a nonhost of GLRaV-7 for several years contained substantial levels of GLRaVRNA, whereas virus-free dodder of the same species was clearly negative. $U$. dioica plants used for maintenance of GLRaV-7-infected $C$. reflexa remained virus-free in RT-PCR tests.

While $C$. reflexa did not flower under greenhouse conditions, $C$. europea and $C$. campestris senesce naturally after flowering and seed production. This characteristic precluded $C$. europea for further transmission tests, whereas GLRaV-7-positive C. campestris could be maintained on $N$. occidentalis by constant vegetative propagation, although with difficulty.
Tobacco plants used for growing infected $C$. campestris remained symptomless, and GLRaV-7 could not be detected by RT-PCR. GLRaV-7 in T. expansa as well as in $N$. occidentalis was transmitted successfully by grafting but not by mechanical inoculation. Seedlings from GLRaV-7-infected dodder plants remained free of GLRaV-7.

Quantification of GLRaV-7. Real-time PCR was performed to quantify GLRaV-7 in different hosts and tissues. Standard curves of six duplicated sample dilutions were generated (Fig. 5). The correlation between the PCR threshold (PCR cycle number) and $\log$ starting quantity was high, with $R^{2}=0.975$ for the standard curve, which indicates high sensitivity, good linearity, and a wide dynamic range.

The highest number of RNA copies was found in the respective tissues of $N$. occidentalis followed by $T$. expansa, $C$. reflexa, and grapevine (Fig. 6). Root phloem of $N$. occidentalis showed the highest amount of RNA, with more than $10^{10}$ copies per milligram of tissue followed by $T$. expansa with more than $4 \times 10^{9}$ copies per milligram of root phloem tissue. Grapevine, the natural host of GLRaV-7, revealed an RNA copy number two to three orders of magnitude lower in the analyzed tissues of leaf midribs and roots compared to the herbaceous plants. Only the stem phloem of

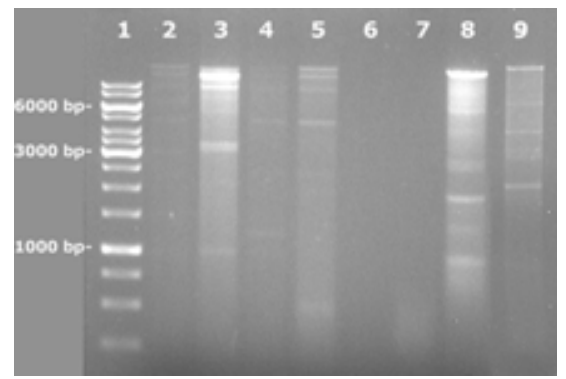

Fig. 2. Agarose gel analysis of double-stranded RNA extracted from Grapevine leafrollassociated virus-7-infected plant material. Lane: (1) 1-kb ladder (Fermentas); (2) Cuscuta reflexa; (3) C. campestris; (4) Tetragonia expansa; (5) Nicotiana occidentalis 37B; (6) healthy $N$. occidentalis; (7) healthy T. expansa; (8) Beet yellows virus (BYV) as molecular weight standard (BYV genome size $15.5 \mathrm{~kb}$ ); (9) Vitis vinifera. High molecular bands correspond with full viral genome from BYV (genome size $15.5 \mathrm{~kb}$ ), lower bands correspond with subgenomic RNA pointing out replication of virus in host.

Table 1. Results of virus transmission experiments with three dodder species ${ }^{\mathrm{a}}$

\begin{tabular}{lccc}
\hline & \multirow{2}{*}{$\begin{array}{c}\text { Detection of } \\
\text { Dodder vector }\end{array}$} & \multicolumn{2}{c}{ Transfer of GLRaV-7 to } \\
\cline { 3 - 4 } & GLRaV-7 in dodder & Nicotiana occidentalis & Tetragonia expansa \\
\hline Cuscuta reflexa & $\checkmark$ & No & $\checkmark$ \\
Cuscuta campestris & $\checkmark$ & No & No \\
Cuscuta europea & $\checkmark$ & $\checkmark$ & No \\
\hline
\end{tabular}

${ }^{a}$ In all cases, virus donor was a grapevine infected with Grapevine leafroll-associated virus-7 (GLRaV-7) accession AA42. N. occidentalis was the only experimental host showing symptoms after infection with GLRaV-7. C. campestris was the only dodder that was not able to transfer the virus to a new host. Checkmarks indicate successful transfer or detection of GLRaV-7.
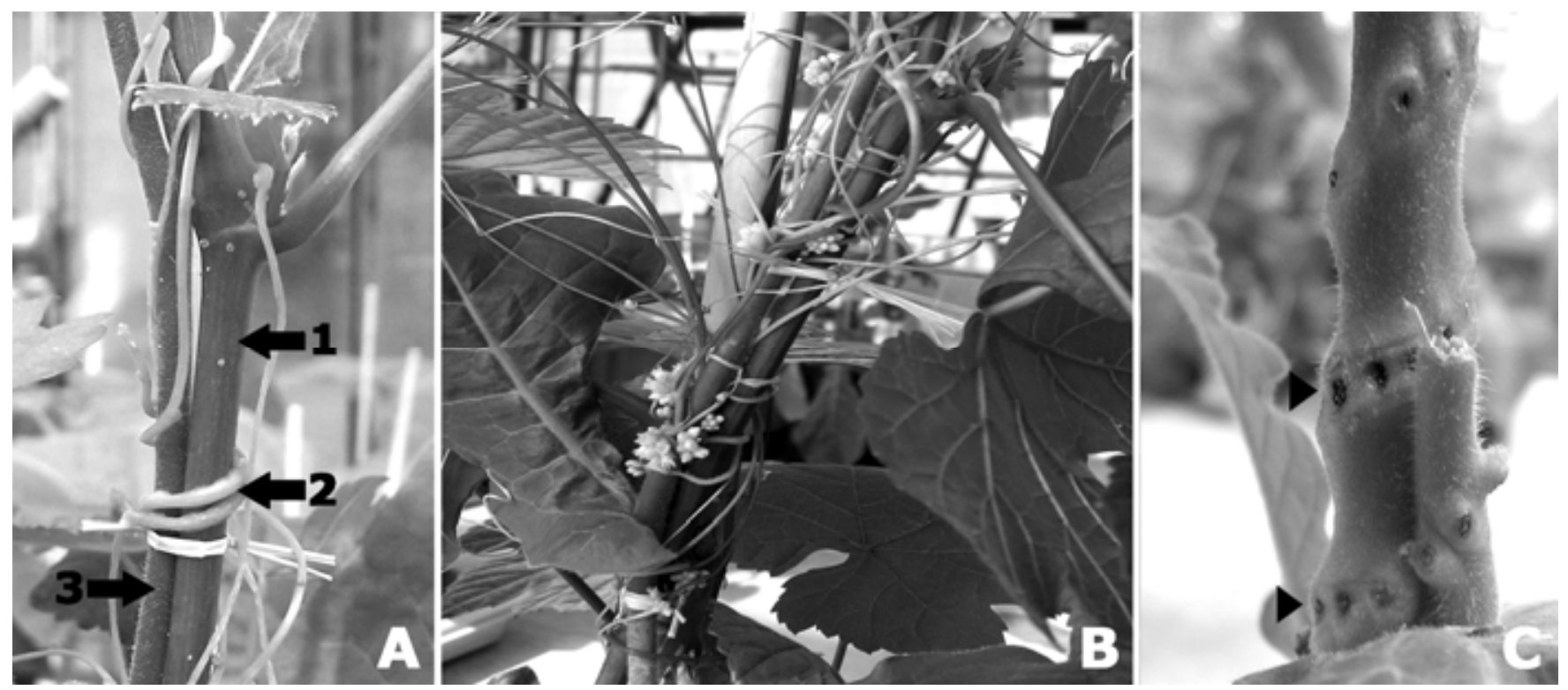

Fig. 1. A, Transmission experiment with Grapevine leafroll-associated virus-7 (GLRaV-7) infected grapevine (arrow 1), parasitic Cuscuta reflexa acting as vector (2) and healthy Nicotiana occidentalis 37B (3). Stems of GLRaV-7-infected grapevine and healthy tobacco were bound together. Dodder shoots were attached around stems of host plants in a counter-clockwise manner. B, Transmission experiment with Cuscuta europea acting as phloem bridge. The vector transferred the virus from grapevine to tobacco. C. europea is drying out after flowering and seed production. C, Parasite developed haustoria to tap the phloem of its hosts. Arrowheads mark lesions of N. occidentalis that appear after removing parasite from connection site. 
grapevine had a higher copy number than T. expansa phloem tissue, but the same low titer as the parasite $C$. reflexa where no classification in root, stem, or leaf tissue is possible.

\section{DISCUSSION}

This is the first time a virus in the family Closteroviridae was successfully transferred to an herbaceous plant by dodder. Transmissions of members of the family Closteroviridae by dodder have been reported earlier, however, with the natural host as acceptor plant $(10,23,40)$. In the case of Grapevine virus $B$, dodder acquired the virus but was unable to transmit it to the desired recipient plant (11). Because earlier work focused on the infection of a host plant, the infection status of the Cuscuta species was not the objective of the investigation. Hence, it is not always certain in which cases dodder might have been a potential host for viruses $(21,23,26,31,36)$.
We were able to detect GLRaV-7 in all three dodder species used in transmission trials. Due to the short life cycle of $C$. europea, it was not possible to verify the replication of the virus by dsRNA extraction. However, in the case of $C$. reflexa and C. campestris, the virus could be established over several years on host plants that were unable to support GLRaV-7 replication or infection. C. reflexa was maintained on nettle for 4 years and C. campestris over the same period on tobacco.

GLRaV-7 is a single-stranded virus, and the steady presence of its replicative forms of dsRNA in Cuscuta is-together with the fact that GLRaV-7 infections of T. expansa and $N$. occidentalis were sustainable by grafting — strong evidence of GLRaV-7 replication $(8,9,39)$. This is supported by repeated GLRaV-7 dsRNA extractions in equal amounts from new growth of $C$. reflexa held on $U$. dioica (nettle), a nonhost of GLRaV-7. This result cannot be

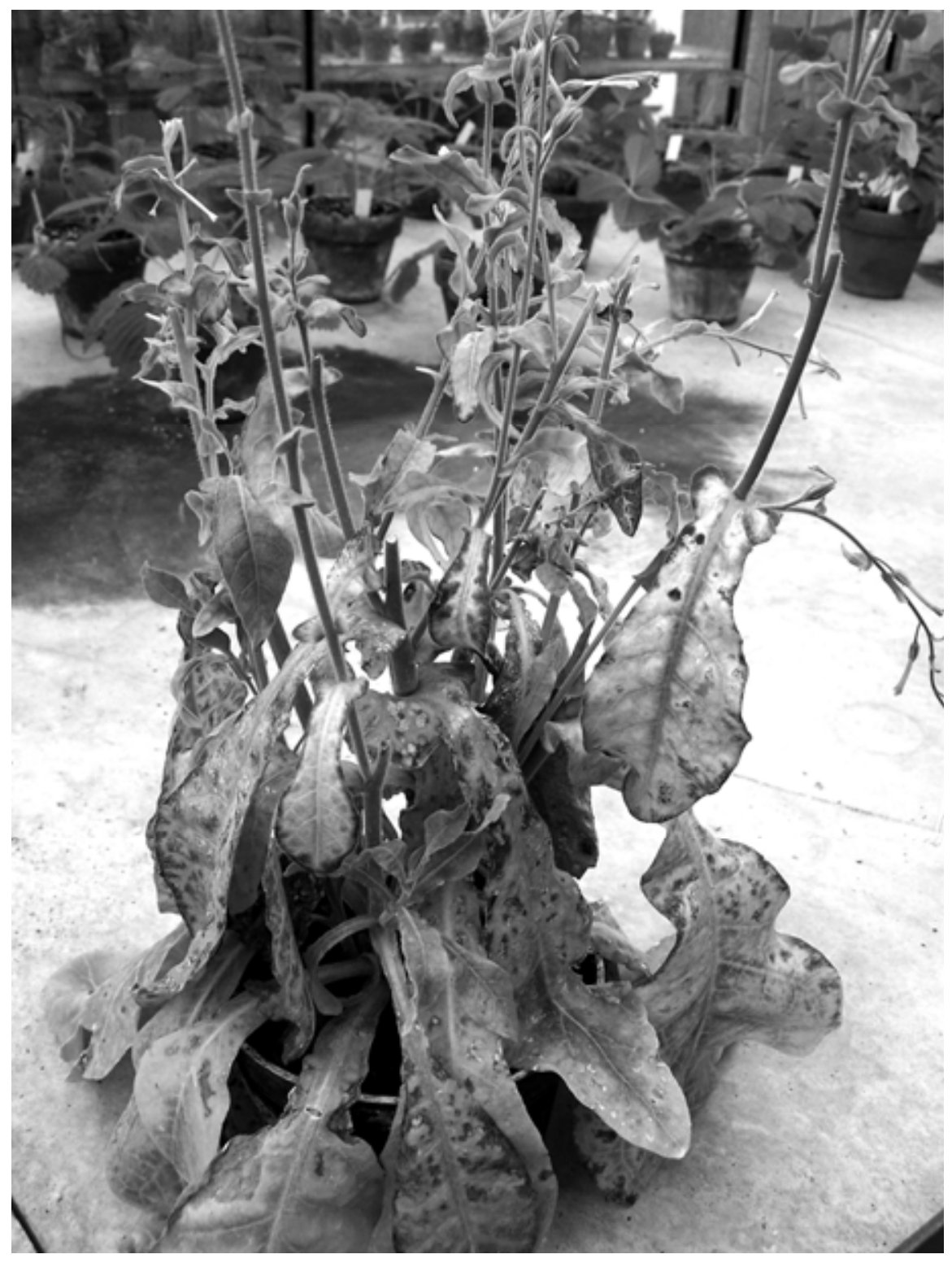

Fig. 3. Two-month-old symptomatic Nicotiana occidentalis 37B plant infected with Grapevine leafroll-associated virus-7. Infection could be maintained by grafting. explained without replication of the virus in dodder. To rule out the possibility of virus uptake from nettle and to ascertain that virus replication took place in dodder, nettle was constantly tested for GLRaV-7 infection. These tests consistently confirmed that the nettle was virus-free. Similarly, tobacco on which $C$. campestris was maintained remained free of virus infection. The absence of GLRaV-7 in these hosts is an indication for its replication in C. reflexa and C. campestris. Earlier reports similarly demonstrated the multiplication of Cucumber mosaic virus in $C$. campestris (6).

Experimental hosts from the families Solanaceae and Cucurbitaceae remained symptomless and virus-free in transmission tests with $C$. reflexa and $C$. campestris. The success of virus transmissions is hardly predictable and depends on the virus under investigation, the dodder species, and the host plants in association with the environmental conditions $(15,32)$. Earlier reports pointed out that Cuscuta species exhibit a multitude of inhibiting agents that could inactivate passing viruses before they were able to reach another host $(1,6,32)$. The differing efficiency of Cuscuta species to transmit the viruses mentioned above led in the present study to the unequal ability of Cuscuta to translocate viruses to a host plant. The phenomenon that one virus was carried through the dodder-bridge while the other was not transferred by this method has been observed before and was utilized to separate two viruses from a mixed infection $(3,16,31,32)$. Our transmission experiments and the detection of GLRaV-7 in $C$. reflexa and $C$. campestris show that this virus is not only able to infect but also to replicate in dodder without being inactivated. Although GLRaV-7 has been established in $C$. campestris, the parasite was unable to transfer the virus to other plants. C. reflexa turned out to be the most suitable viral dodder host due to its nonbudding purely vegetative growth under greenhouse conditions (2), whereas $C$.

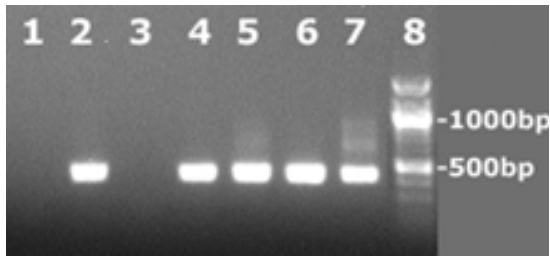

Fig. 4. Polymerase chain reaction (PCR) (Grapevine leafroll-associated virus-7 [GLRaV7] specific primer pair) products of reverse transcribed double-stranded (ds)RNA from GLRaV-7-infected plants. Lane: (1) water control from reverse transcription; (2) positive LR-7 control from total nucleic acid extraction; (3) water control from PCR; (4) Cuscuta reflexa; (5) C. campestris; (6) Tetragonia expansa; (7) Nicotiana occidentalis; (8) 100-bp ladder (NEB). DsRNA extractions responded to the GLRaV-7 specific primer pair. 
europea senesces naturally after seed production and $C$. campestris could only be maintained on $N$. occidentalis with difficulty by constant vegetative propagation. There is no indication for seed transmission of GLRaV-7 since seedlings derived from GLRaV-7-infected herbaceous host plants and Cuscuta remained virus-free.

The real-time PCR assay of GLRaV-7infected woody and herbaceous plant species revealed that the number of viral RNA copies differed greatly between hosts. The highest amount of RNA copies was found in $N$. occidentalis followed by $T$. expansa, $C$. reflexa, and $V$. vinifera. The distribution of RNA copies was unequal between the different organs/tissues and the host plants. The highest amount of viral RNA was detected in roots of $N$. occidentalis and $T$. expansa. This result corresponds with earlier reports on the distribution of viruses in herbaceous host plants (12). The virus under investigation was transmitted by a soilborne fungal vector, and a high virus concentration in roots could be advantageous for transmission (12). Nevertheless, patterns of high accumulation in roots have also been observed for viruses that are not fungus-transmitted, depending on the transport into selective sink organs, the developmental stage of the host, the host's gene-silencing mechanisms, and the viral suppression of gene-silencing $(18,25,37$, $38,43)$. Which of these processes are responsible for the very low virus titer in grapevine roots has not been determined so far.

These transmission experiments show a promising way to access viruses with a difficult extraction profile like those present in woody plants. DsRNA from infected grapevines is obtained by phloem scraping, which is more difficult in summer. Isolations from leaf and petiole material can be carried out, but the virus yield is low. In winter, dsRNA extractions are possible from dormant woody material, but limitations exist regarding the amount of source material and efficiency of purification. Comparing the seasonal availability of viral material, the simplicity of extraction, and the quantitative yield, the new experimental herbaceous hosts, $N$. occidentalis, T. expansa, and the dodder vectors, have a distinct advantage in comparison with the natural host. The use of

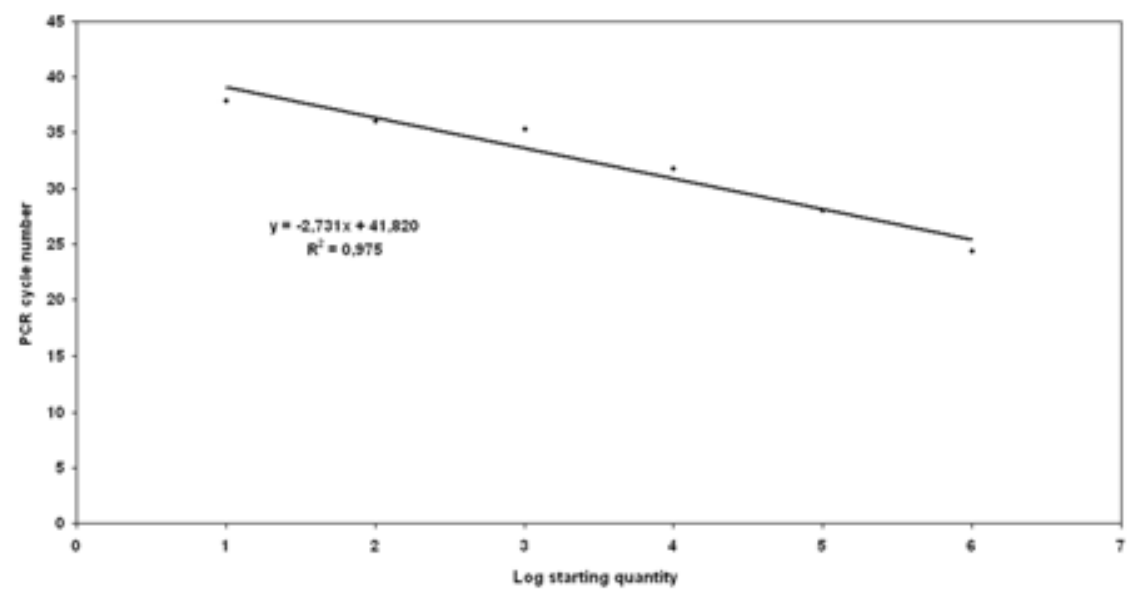

Fig. 5. Standard curve of Grapevine leafroll-associated virus-7, generated by plotting the logarithm of concentration ( 6 serial dilutions from $10^{1}$ to $10^{6}$ copies $/ \mathrm{ml}$ ) against the cycle in which the signal exceeded the threshold point obtained from a real-time polymerase chain reaction (PCR) assay. Linear regression coefficient $(\mathrm{R})$ is given with the equation (y) in the graph.

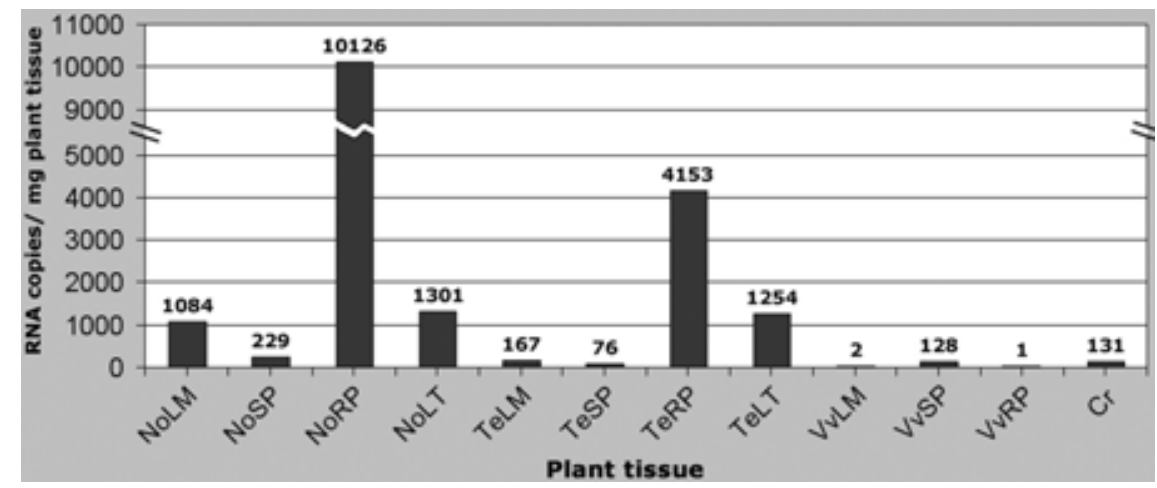

Fig. 6. Number of Grapevine leafroll-associated virus-7 RNA copies in leaf midrib (LM), stem phloem (SP), root phloem (RP), and leaf tissue (LT) of Nicotiana occidentalis 37B (No), Tetragonia expansa $(\mathrm{Te})$, and Vitis vinifera $(\mathrm{Vv})$, and whole shoots of Cuscuta reflexa $(\mathrm{Cr})$. Measurement units are $10^{6} \mathrm{RNA}$ copies/mg plant tissue.

dodder as vector seems to be a feasible method to obtain higher amounts of easyto-access virus source material. Additionally, dodder can be used as a vector for further infection of herbaceous hosts, which subsequently could be used as model plants for etiological investigations or determining the physical properties of viruses. The new source of GLRaV-7 RNA allowed its extraction and the identification of new sequence data of the GLRaV-7 genome.

\section{ACKNOWLEDGMENTS}

Technical assistance from Felix Hergenhahn was greatly appreciated. We thank Jürgen Gross, Bernd Schneider, and Jeremy Thompson for their useful comments on the manuscript. This research was supported by the Deutsche Forschungsgemeinschaft (DFG), Bonn, Grant No. JE 142/8-1.

\section{LITERATURE CITED}

1. Awasthi, L. P. 1981. The purification and nature of an antiviral protein from Cuscuta re flexa plants. Arch. Virol. 70:215-223.

2. Barbat, I., and Pop, E. 1970. Preferential flowering of Cuscuta reflexa in continuous darkness. Naturwissenschaften 57:136.

3. Bennett, C. W. 1940. Acquisition and transmission of viruses by dodder (Cuscuta subinclusa). Phytopathology 30:2.

4. Birschwilks, M., Haupt, S., Hofius, D., and Neumann, S. 2006. Transfer of phloem-mobile substances from the host plants to the holoparasite Cuscuta sp. J. Exp. Bot. 57:911-921.

5. Choueiri, E., Boscia, D., Digiaro, M., Castellano, M., and Martelli, G. 1996. Some properties of a hitherto undescribed filamentous virus of the grapevine. Vitis 35:91-93.

6. Costa, A. S. 1944. Multiplication of viruses in the dodder Cuscuta campestris. Phytopathology 34:151-162.

7. Demeke, T., and Adams, R. P. 1992. The effects of plant polysaccharides and buffer additives on PCR. Biotechniques 12:332-334.

8. Dodds, J. A., and Barjoseph, M. 1983. Doublestranded RNA from plants infected with Closteroviruses. Phytopathology 73:419-423.

9. Dodds, J. A., Morris, T. J., and Jordan, R. L. 1984. Plant viral double-stranded RNA. Annu. Rev. Phytopathol. 22:151-168.

10. Fuchs, W., and Beiss, U. 1954. Transmission of the Beet yellows virus (Corium betae) with the aid of Cuscuta. Naturwissenschaften 41:506

11. Garau, R., Prota, V., Boscia, D., Piredda, R. and Prota, U. 1993. Studies on Grapevine virus $\mathrm{B}$ isolates from corky bark-affected vines in Sardinia. Riv. Patol. Veg. 3:83-89.

12. Gosalvez-Bernal, B., Genoves, A., Navarro, J. A., Pallas, V., and Sanchez-Pina, M. A. 2008 Distribution and pathway for phloemdependent movement of Melon necrotic spot virus in melon plants. Mol. Plant Pathol. 9:447-461.

13. Habili, N., and Rezaian, M. A. 1995. Cloning and molecular analysis of double-stranded RNA associated with grapevine leafroll disease. Ann. Appl. Biol. 127:95-103

14. Haupt, S., Oparka, K. J., Sauer, N., and Neumann, S. 2001. Macromolecular trafficking between Nicotiana tabacum and the holoparasite Cuscuta reflexa. J. Exp. Bot. 52:173-177.

15. Hosford, R. M. 1967. Transmission of plant viruses by dodder. Bot. Rev. 33:387-406.

16. Johnson, F. 1941. Transmission of viruses by the parasitic activities of dodder. Phytopathology $31: 13$.

17. Keim-Konrad, R., and Jelkmann, W. 1996. Genome analysis of the 3 '-terminal part of the little cherry disease associated dsRNA reveals 
a monopartite clostero-like virus. Arch. Virol. 141:1437-1451.

18. Lunello, P., Mansilla, C., Sanchez, F., and Ponz, F. 2007. A developmentally linked, dramatic, and transient loss of virus from roots of Arabidopsis thaliana plants infected by either of two RNA viruses. Mol. Plant-Microbe Interact. 20:1589-1595.

19. Marcone, C., Hergenhahn, F., Ragozzino, A., and Seemuller, E. 1999. Dodder transmission of pear decline, European stone fruit yellows, rubus stunt, Picris echioides yellows and cotton phyllody phytoplasmas to periwinkle. J. Phytopathol.-Phytopathol. Z. 147:187-192.

20. Martelli, G. P., Agranovsky, A. A., Bar-Joseph, M., Candresse, T., Coutts R. H. A., Dolja, V. V., Falk, B. W., Gonsalves, D., Jelkmann, W., Karasev, A. V., Minafra, A., Namba, S., Vetten, H. J., Wisler, G. C., and Yoshikawa, N. 2003. The family Closteroviridae revised. Arch. Virol. 147:2039-2044.

21. Mossahebi, G., Okhovvat, S., and Damadi, M. 2005. Determination of the races of Potato virus $\mathrm{X}$ and its host range in Karaj, Damavand and Ardabil, Iran. Comm. Agric. Appl. Biol. Sci. 70:431-433.

22. Mower, J. P., Stefanovic, S., Young, G. J., and Palmer, J. D. 2004. Plant genetics - Gene transfer from parasitic to host plants. Nature 432:165-166.

23. Nariani, T., and Raychandhum, S. 1970. Transmission of Citrus tristeza virus by dodder, Cuscuta reflexa Roxb. Ann. Phytopathol. Soc. Jpn. 36:289-290.

24. Neyland, R. 2001. A phylogeny inferred from large ribosomal subunit (26S) rDNA sequences suggests that Cuscuta is a derived member of Convolvulaceae. Brittonia 53:108-115.

25. Oparka, K. J., and Cruz, S. S. 2000. The great escape: Phloem transport and unloading of macromolecules. Annu. Rev. Plant Physiol.
Plant Mol. Biol. 51:323-347.

26. Raine, J., Mcmullen, R. D., and Forbes, A. R. 1986. Transmission of the agent causing little cherry disease by the apple mealybug Phenacoccus aceris and the dodder Cuscuta lupuliformis. Can. J. Plant Pathol.-Rev. Can. Phytopathol. 8:6-11.

27. Roney, J. K., Khatibi, P. A., and Westwood, J. H. 2007. Cross-species translocation of mRNA from host plants into the parasitic plant dodder. Plant Physiol. 143:1037-1043.

28. Rott, M. E., and Jelkmann, W. 2001. Characterization and detection of several filamentous viruses of cherry: Adaptation of an alternative cloning method (DOP-PCR), and modification of an RNA extraction protocol. Eur. J. Plant Pathol. 107:411-420.

29. Saldarelli, P., Rowhani, A., Routh, G., Minafra, A., and Digiaro, M. 1998. Use of degenerate primers in a RT-PCR assay for the identification and analysis of some filamentous viruses, with special reference to clostero- and vitiviruses of the grapevine. Eur. J. Plant Pathol. 104:945-950.

30. Sambrook, J., and Russell, D. W. 2006. The Condensed Protocols from Molecular Cloning: A Laboratory Manual. Cold Spring Harbor Laboratory, Cold Spring Harbor, NY.

31. Schmelzer, K. 1956. Beiträge zur Kenntnis der Übertragbarkeit von Viren durch CuscutaArten. Phytopathol. Z. 28:1-56.

32. Schmelzer, K. 1956. Beiträge zur Kenntnis der Virushemmstoffe in Cuscuta-Arten. Zentralblatt für Bakteriologie, Parasitenkunde, Infektionskrankheiten u. Hygiene 109:481-515.

33. Stefanovic, S., Krueger, L., and Olmstead, R. G. 2002. Monophyly of the Convolvulaceae and circumscription of their major lineages based on DNA sequences of multiple chloroplast loci. Am. J. Bot. 89:1510-1522.

34. Stefanovic, S., and Olmstead, R. G. 2004.
Testing the phylogenetic position of a parasitic plant (Cuscuta, Convolvulaceae, Asteridae) Bayesian inference and the parametric bootstrap on data drawn from three genomes. Syst. Biol. 53:384-399.

35. Tanne, E., Sela, I., and Harpaz, I. 1974 Transmission of grapevine leafroll virus to herbaceous plants. Phytopathol. Z. 80:176180 .

36. Tomlinson, J. A., and Garrett, R. G. 1964. Studies on Lettuce Big-Vein Virus + Its Vector Olpidium Brassicae (Wor) Dang. Ann. Appl. Biol. 54:45-61.

37. Valentine, T., Shaw, J., Blok, V. C., Phillips, M. S., Oparka, K. J., and Lacomme, C. 2004 Efficient virus-induced gene silencing in roots using a modified tobacco rattle virus vector Plant Physiol. 136:3999-4009.

38. Valentine, T. A., Roberts, I. M., and Oparka, K. J. 2002. Inhibition of tobacco mosaic virus replication in lateral roots is dependent on an activated meristem-derived signal. Protoplasma 219:184-196.

39. Valverde, R. A., Nameth, S. T., and Jordan, R. L. 1990. Analysis of double-stranded RNA for plant virus diagnosis. Plant Dis. 74:255-258.

40. Weathers, L., and Harjung, M. 1964. Transmission of citrus viruses by dodder, Cuscuta subinclusa. Plant Dis. Rep. 48:102-103.

41. Woodham, R. C., and Krake, L. R. 1983. Investigations on transmission of grapevine leafroll, yellow speckle and fleck diseases by dodder. Phytopathol. Z.-J. Phytopathol. 106:193-198.

42. Yuncker, T. G. 1932. The genus Cuscuta. Mem. Torrey Bot. Club 18:109-331.

43. Zhu, Y. L., Qi, Y. J., Xun, Y., Owens, R., and Ding, B. 2002. Movement of potato spindle tuber viroid reveals regulatory points of phloem-mediated RNA traffic. Plant Physiol. 130:138-146. 